$\S=-1$

\title{
Groundwater Quality Assessment of Ambuliyar Watershed using GIS
}

\author{
Keerthana Devi $\mathbf{R}^{1}$, Balaji $\mathbf{D}^{2}$, Natarajan $\mathbf{H}^{3}$, Nasir $\mathbf{N}^{4}$, Selvakumar $\mathbf{R}^{5}$ \\ ${ }^{1,2,3}$ Students, ${ }^{4}$ Research Scholar, ${ }^{5}$ Assistant Professor, \\ ${ }^{1,2,3,4,5}$ School of Civil Engineering, SASTRA Deemed University, Thanjavur, Tamil Nadu, India \\ *Corresponding Author Email: ${ }^{5}$ selvakumar@civil.sastra.edu
}

\begin{abstract}
Groundwater is significant in satisfying domestic and agricultural needs.Besides scarcity, the groundwater resource is degrading drastically around the world. The Ambuliyar watershed falling in parts of Tamil Nadu also faces similar problems. To decipher the quality degradation, pre-monsoon and post-monsoon data on various physical and chemical parameters was collected for 29 wells for the year 2014 from Public Works Department. Spatial maps were generated on the above geochemical parameters and categorized into five classes using GIS software. Weights were assigned for each parameter based on their relative importance in with each other parameters. Finally, quality index map was generated by integrating them, and subsequently their aerial extent in monsoons was worked out. During the post-monsoon period, $18 \%$ of the study area represents "excellent", $46 \%$ "good", $25 \%$ shows "moderate" and $11 \%$ shows "poor" quality. While during pre-monsoon period, $34 \%$ of the area exhibits "excellent", $43 \%$ " moderate", and the remaining $23 \%$ of "poor".
\end{abstract}

Keywords: Groundwater quality, Ambuliyar watershed, GIS, Pre-Monsoon, Post Monsoon.

\section{Introduction}

In India, both rural and urban population depends primarily on groundwater for their basic needs (Reddy et al., 1996). Owing to over-exploitation and population explosion the available resource is becoming scarce in many parts of India. Further, pollution from point and non-point sources like domestic, industrial, and agricultural wastewater too degrade the available limited resource. In addition, the adverse impact of global climate change is also imposing major threat. Hence effective utilization and management of the resource for both present and future generations is essential. Pollution added to quality deterioration, threatens the ecological and socio-economic aspects (Milovanovic, 2007). Therefore, it is essential to periodically assess and monitor the quality (Simeonov et al., 2003). Models are developed to better understand the water quality parameters (Kumar and Ahmed, 2003; Suk and Lee, 1999). Amongst, remote sensing and GIS has proven an effective tool in spatially analyzing the water quality. Especially, GIS is used for mapping, estimating and modeling groundwater pollution. Ahn and Chon (1999) spatially correlated groundwater contamination with parameters like topography, geology, landuse, and so on in Seoul.Yammani, (2007) based on the quality prepared suitability map for irrigation and domestic. Rangzan et al., (2008) identified possible locales of well construction based on water quality and availability. Accordingly in the present study, using GIS spatial distribution pattern of on various quality parameters were analysed.

\section{Data and Methodology}

The Ambuliyar sub-basin covers an area of 930 sq. km with its parts falling in Pudukottai and Thanjavur districts, Tamil Nadu.The riverruns from Thiruvarangulam, AlangudiTaluk, Pudukkottai District and confluences with the Bay of Bengal.Base map was perpared using Survey of India (OSM) Topographic sheets $58 \mathrm{~J} 15,58 \mathrm{~J} 16,58 \mathrm{~N} 3,58 \mathrm{~N} 4,58 \mathrm{~N} 7$ \& $58 \mathrm{~N} 8$ on $1: 50,000$ scale.A thorough survey of Ambuliyar watershed was done and a base map was prepared(Figure.1). Subsequently, hydro geochemical parameters namely $\mathrm{pH}$, total dissolved solids, NO3, $\mathrm{Ca}, \mathrm{Mg}$. Na, K, Cl, SO4, CO3, HCO3, F and pH collected from the State Surface and Groundwater Data Centre, Public Works Department, Chennai. The data includes pre-monsoon (July-2014) and post-monsoon (January-2014) for 29 wells. Unit of measure for the concentrations of these various chemical parameters is milligram/litre except pHand turbidity. The location of the wells was geo-tagged. Using inverse distance weighted (IDW) method, contours are generated for each parameter and later based on Indian Standard Specification for Drinking Water (IS: 10500), classified maps were generated. Later to assess the combined impact of different parameters on drinking criteria, a methodology had been devised to prepare water quality index of the study area. Thus the present study is aimed to analyse the pre and postmonsoon spatial distribution pattern of individual parameters and to preparegroundwater quality index map. 


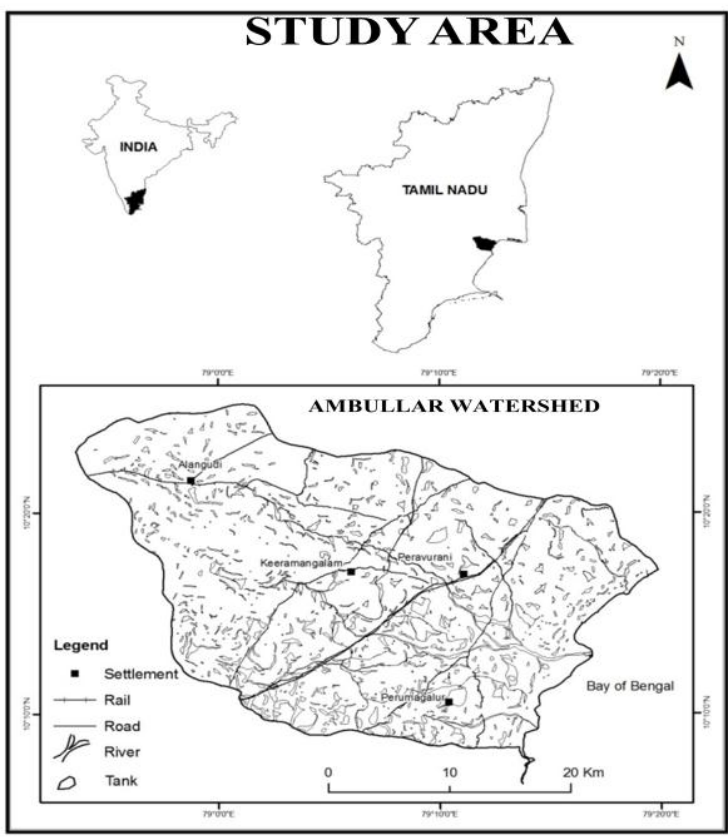

Fig. 1: Map showing study area

\section{Analysis of Groundwater Quality Parameters}

\subsection{Total Dissolved Solids Concentration}

The maximum TDS during the pre-monsoon and post monsoon was $6397 \mathrm{mg} / \mathrm{l}$ and $4301 \mathrm{mg} / \mathrm{l}$ respectively. Desirable value as per BIS standard is $500 \mathrm{mg} / \mathrm{l}$ and the permissible limitis $2000 \mathrm{mg} / \mathrm{l}$. Perusal of the map shows that in both the seasons the TDS is increasing from south western part to the north eastern part with the maximum values concentrated in the south western part. In general, higher concentrations are attributed to the seepage of contaminated water from open drains. Further the host rocks is granitic gneiss which might imposed oxidation and reduction processes leading to enrichment of total dissolved solids(Figure.2).
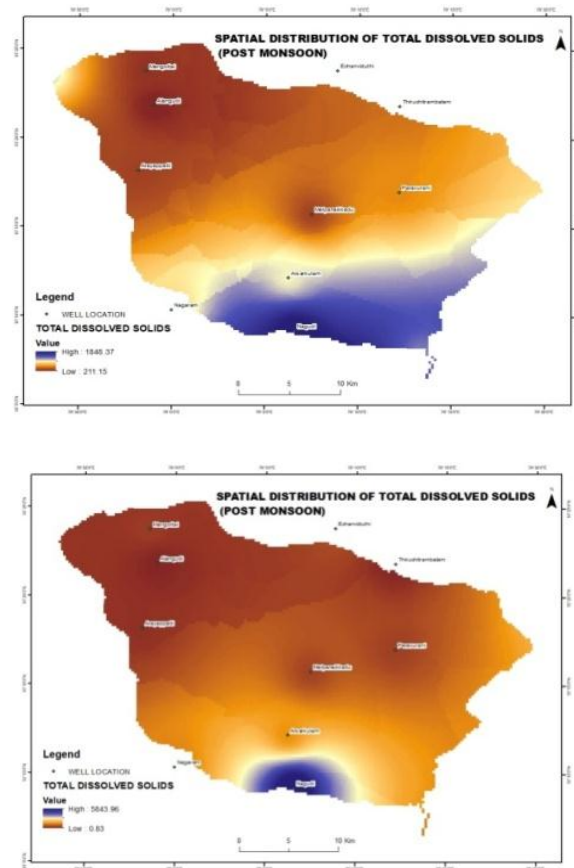

Fig. 2: Thematic map showing concentration of TDS

\subsection{Nitrite Concentration}

Average value of Nitrite (NO2_NO3) concentration in the groundwater exhibits a variation with $5 \mathrm{mg} / \mathrm{l}$ and $6 \mathrm{mg} / \mathrm{l}$ during pre and postmonsoon period. Desirable limit of NO3 is $10 \mathrm{mg} / \mathrm{l}$ and the permissible limit is $50 \mathrm{mg} / \mathrm{l}$ (BIS, 1991). From the table-1, the maximum Nitrate concentration is observed to be less than the permissible limit in both the seasons. Thus it can be surmised as the study area is free from Nitrate contamination. However amongst the measured data, higher concentration is noticed in the north eastern and the south western parts. Nitrate contamination is strongly related to land use pattern. During post monsoon period, the agricultural activities will be intensified and the same is attributed to higher concentration especially in the downstream of the watershed (Figure.3).
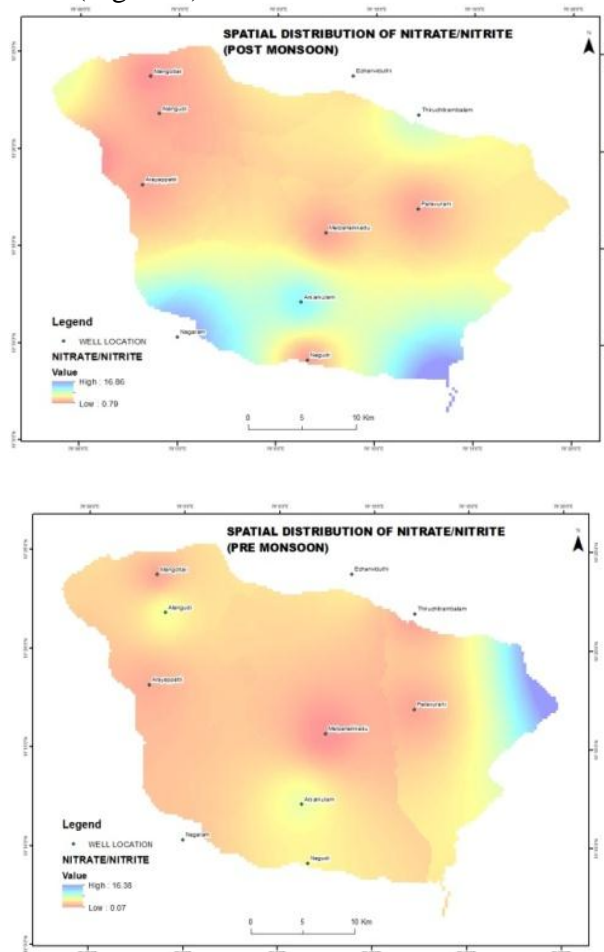

Fig. 3: Thematic map showing concentration of Nitrate/Nitrite

\subsection{Calcium Concentration}

The average Calcium concentration in the groundwater varies from $34 \mathrm{mg} / \mathrm{l}$ to $47 \mathrm{mg} / \mathrm{l}$ in pre and post monsoon. Both from figure. 4 and table- 1 , the concentration of Caseems to be within BIS standard limits $(70 \mathrm{mg} / \mathrm{L}$ and $200 \mathrm{mg} / \mathrm{L})$. However amongst derived values a higher concentration is observed in the southern part. In general calcium is derived from the weathering of feldspar rich rocks. Thus presence of $\mathrm{Ca}$ is once again attributed to the lithology of the area(Figure.4).

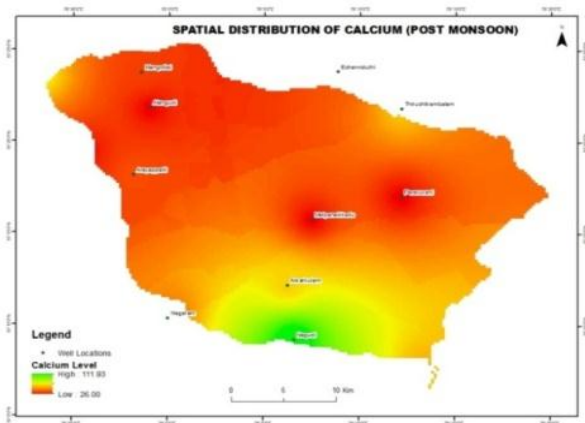




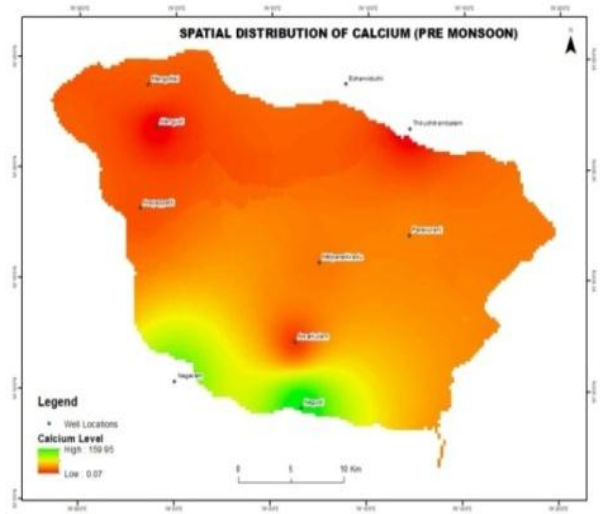

Fig. 4: Thematic map showing concentration of Calcium

\subsection{Magnesium Concentration}

The average value of magnesium was $383.88 \mathrm{mg} / \mathrm{l}$ and $72 \mathrm{mg} / \mathrm{l}$ during the monsoons. As per BIS (1991) the limits are $30 \mathrm{mg} / \mathrm{l}$ and $100 \mathrm{mg} / \mathrm{l}$. The magnesium content seems to be very high in both the monsoons in the south (Figure.5).Once again the leaching of host is attributed for anomalous concentration magnesium.
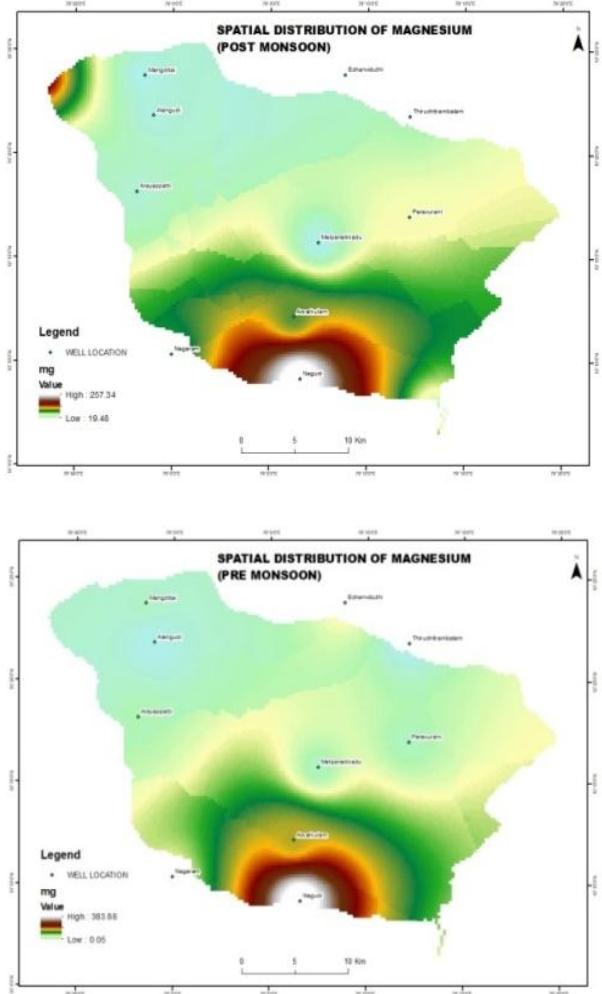

Fig. 5: Thematic map showing concentration of Magnesium

\subsection{Sodium Concentration}

The average value of sodium during pre-monsoon was $270 \mathrm{mg} / \mathrm{l}$, whereas during post monsoon it was $216 \mathrm{mg} / \mathrm{l}$. The desirable value for $\mathrm{Na}$ is $200 \mathrm{mg} / \mathrm{l}$ (BIS, 1991). Spatial distribution shows that the sodium concentration is high in the south eastern part during pre and almost within prescribed limit during post monsoon period. Excess concentration during the pre-monsoonis attributed to chemical weathering of granitic gneiss and the absence during post monsoon to the dilution of concentration due to rainfall (Figure.6).
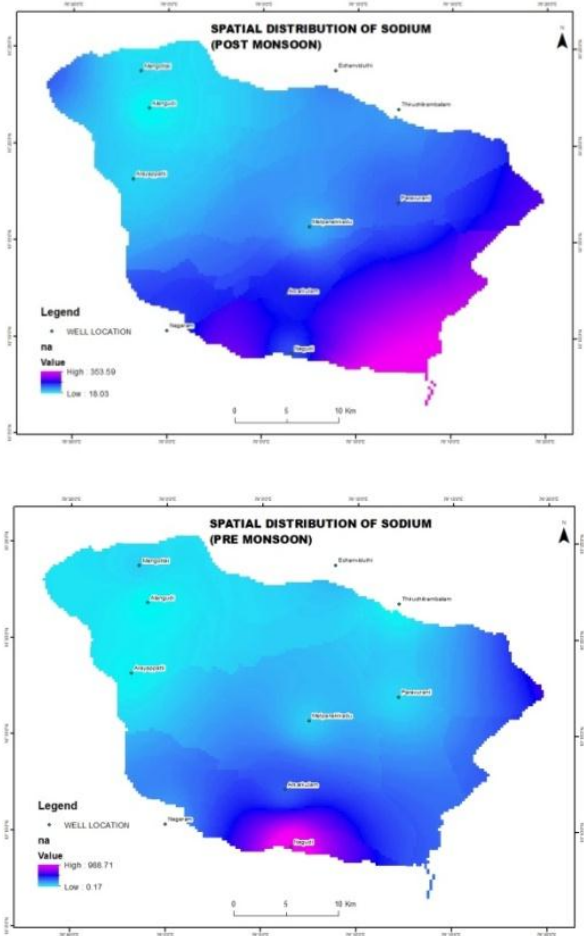

Fig. 6: Thematic map showing concentration of Sodium

\subsection{Potassium Concentration}

The average value of potassium during pre-monsoon was $10 \mathrm{mg} / \mathrm{l}$ whereas during post-monsoon the value was $13 \mathrm{mg} / \mathrm{l}$. However a maximum potassium concentration of $43 \mathrm{mg} / \mathrm{l}$ and $70 \mathrm{mg} / \mathrm{l}$ is noticed (table-1). The BIS limits $25 \mathrm{mg} / \mathrm{l}$ and $30 \mathrm{mg} / \mathrm{l}$ as permissible and desirable values. The excess concentration is observed in the south eastern during the pre monsoon and in the middle and southern portion during post monsoon period. Chemical weathering is attributed to the concentration in premonsoon time while agricultural activities for post monsoon concentration(Figure.7).
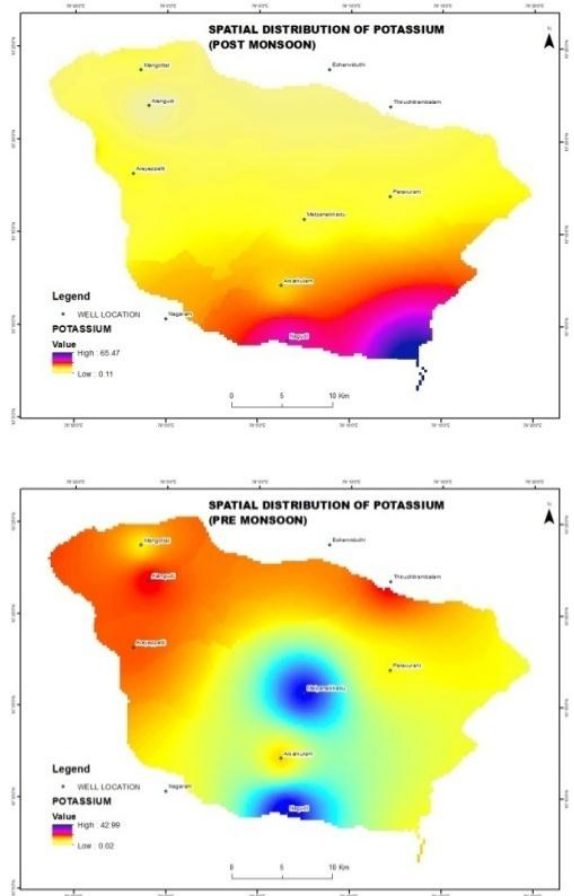

Fig. 7: Thematic map showing concentration of Potassium 


\subsection{Chloride Concentration}

In groundwater, Chloride occurs in varying concentrations. In natural water, the concentration will be less than $100 \mathrm{mg} / \mathrm{l}$ while in brackish or saline water the concentration increases. Chloride originates both from natural and manmade activities like sewage and industrial effluents, urban runoff, and so on (WHO, 2004). Though the average value of Chloride during was $620 \mathrm{mg} / \mathrm{l}$ and390 mg/l during pre and post-monsoons, maximum value shows a very high concentrations. The Desirable value: $250 \mathrm{mg} / \mathrm{L}$ and Permissible value: $1000 \mathrm{mg} / \mathrm{L}$ for chlorine content. However, perusal of the GIS map shows higher concentration in the southern part during both the seasons (Figure.8)
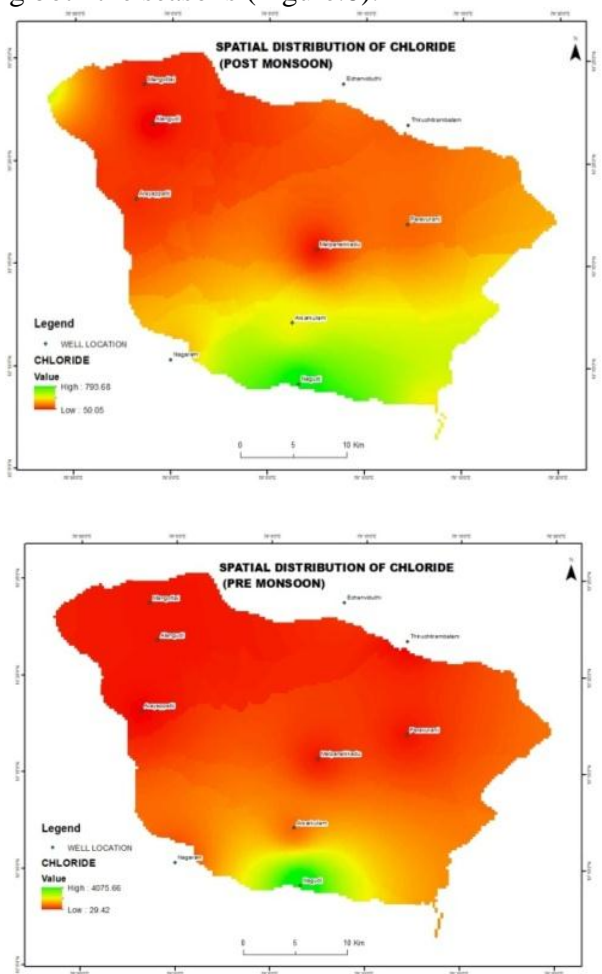

Fig. 8: Thematic map showing concentration of Chloride

\subsection{Sulphate Concentration}

Though the desirable and permissible values are $200 \mathrm{mg} / \mathrm{l}$ and 400 $\mathrm{mg} / \mathrm{l}$ (BIS, 1991), a higher concentration is noticed in both the seasons. In general the leaching of metamorphic rock is considered as the reason for increased Sulphate concentration. However, the release of Sulphur gas due to anthropogenic activities gets oxidized and enters into the groundwater (Figure.9).

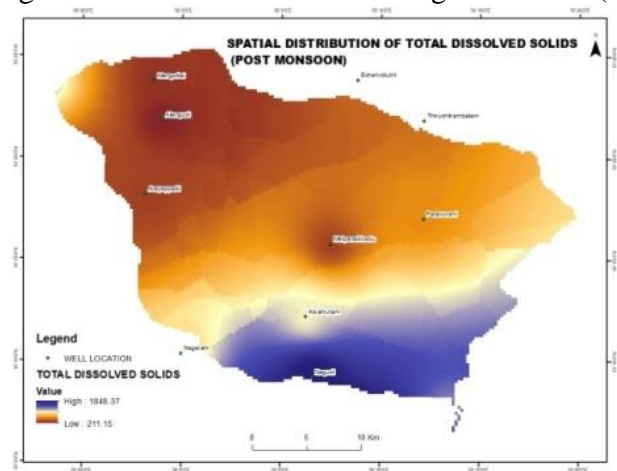

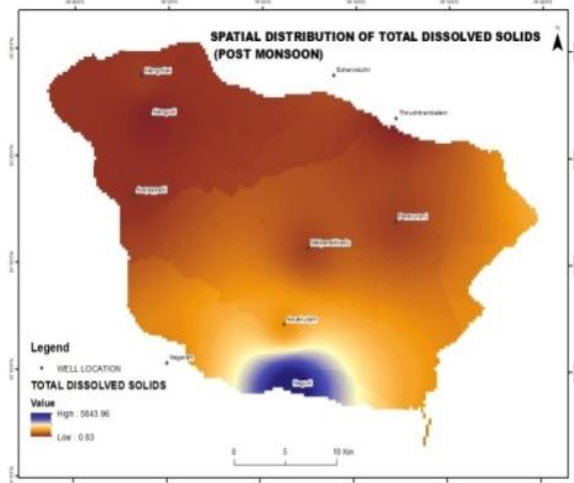

Fig. 9: Thematic Maps of Sulphate (Post monsoon and Pre Monsoon)

\subsection{Hydrogen Carbonate Concentration}

The average value of $\mathrm{HCO} 3$ was $159 \mathrm{mg} / \mathrm{l}$ and $280 \mathrm{mg} / \mathrm{l}$, which is well within the BIS prescribed desirable value $(500 \mathrm{mg} / \mathrm{l})$. But a maximum concentration values of around 650 is noticed along the coastal tracts I both the seasons (Table-1 \&Figure.10).
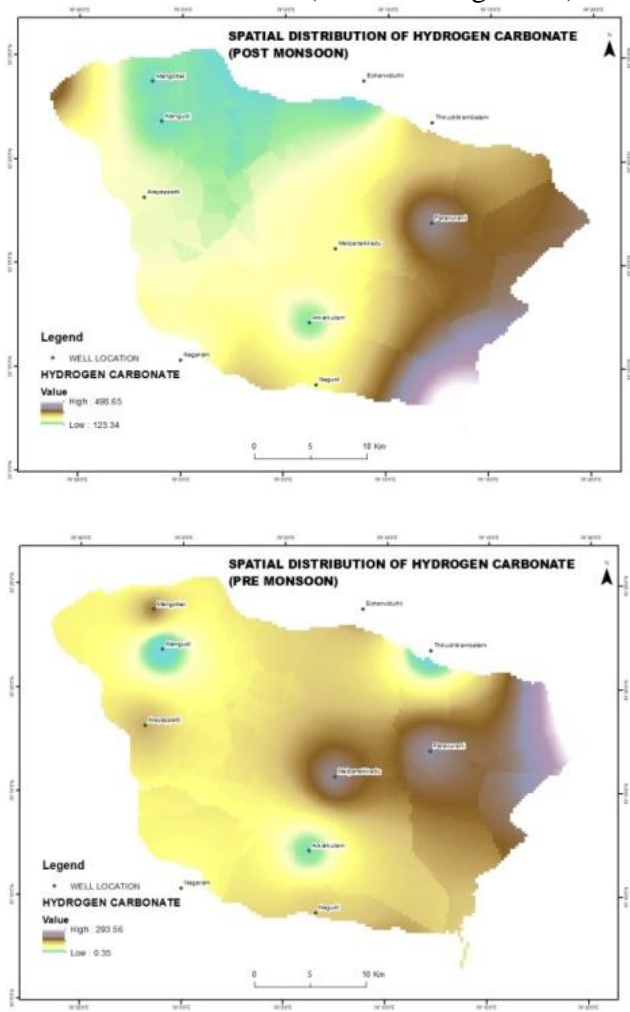

Fig. 10: Thematic map showing concentration of Hydrogen Carbonate

\section{$3.10 \mathrm{pH}$ Concentration}

The study area exhibits a maximum $\mathrm{pH}$ value of 8 during both the seasons which is well within the BIS prescribed limit of6.5 and 8.5. The release of sodium and calcium ions due to weathering of plagioclase feldspar along with dissolved atmospheric carbon dioxide increases $\mathrm{pH}$ and alkalinity in water. The study area exhibits $\mathrm{pH}$ value well within the recommended WHO standards(Figure.11). 

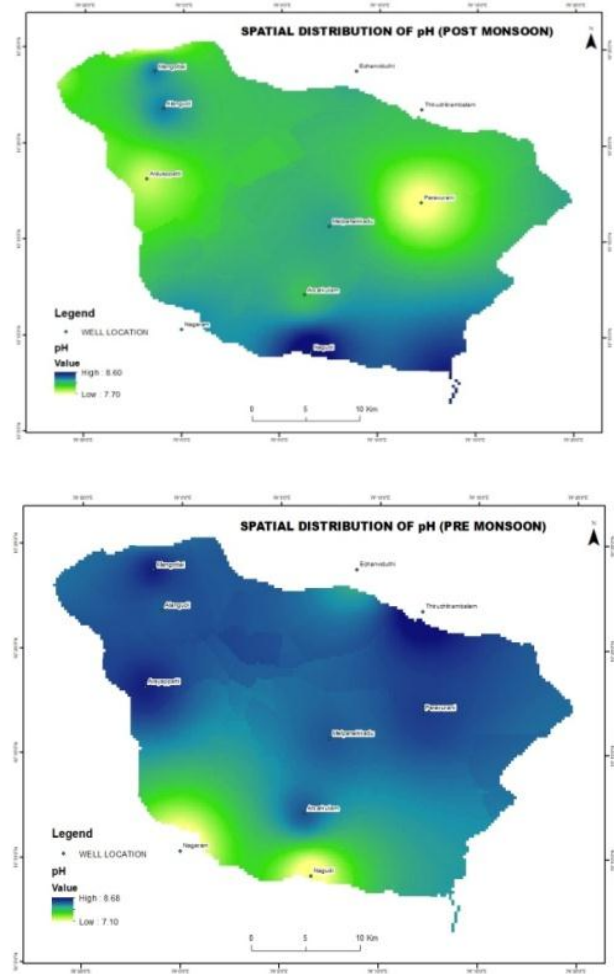

Fig. 11: Thematic map showing concentration of $\mathrm{pH}$

\subsection{Fluoride Concentration}

The Desirable and permissible values of Fluoride is $1.0 \mathrm{mg} / \mathrm{L}$ and $1.5 \mathrm{mg} / \mathrm{L}$ (BIS, 1991). From table-1, a mean value of 0.45 $\mathrm{mg} / \mathrm{l}$ and $0.5 \mathrm{mg} / \mathrm{l}$ was inferred. However, maximum permissible value of $1.5 \mathrm{mg} / \mathrm{l}$ is noticed in the middle during post monsoon period and the same seems to be diluted after the monsoon. Thus the increase might be attributed to the underlying lithology (Figure.12)
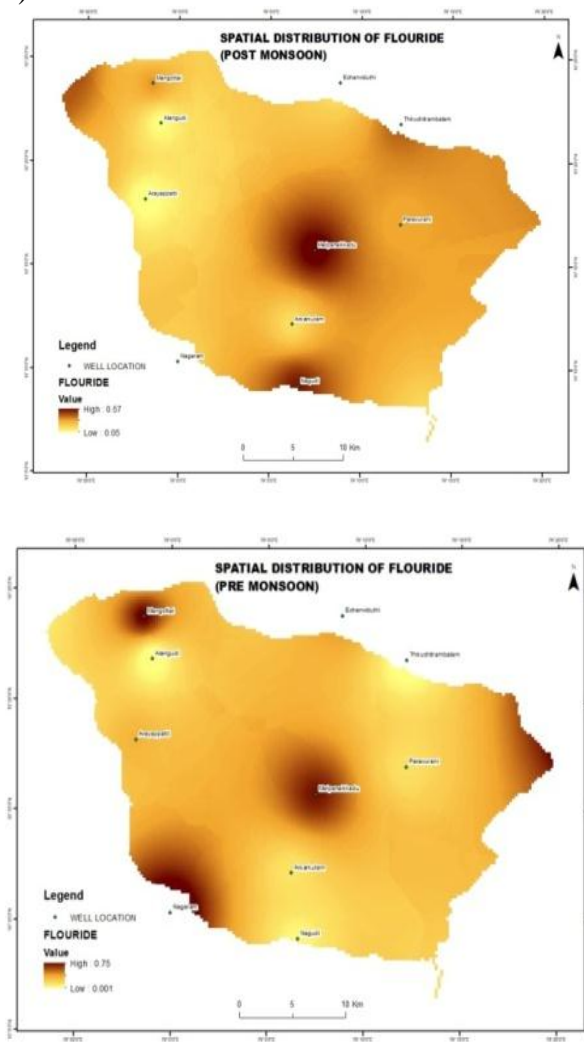

Fig. 12: Thematic map showing concentration of Fluoride

\subsection{Electrical Conductivity Concentration}

Electrical conductivity indirectly depicts the hardness of the water. The permissible limit is 300 micro Siemens. In the study area event the mean EC value exceeds the permissible limit on both the seasons (Table-1). Figure shows high concentration electrical conductivity in southern partsof the study (Figure.13).
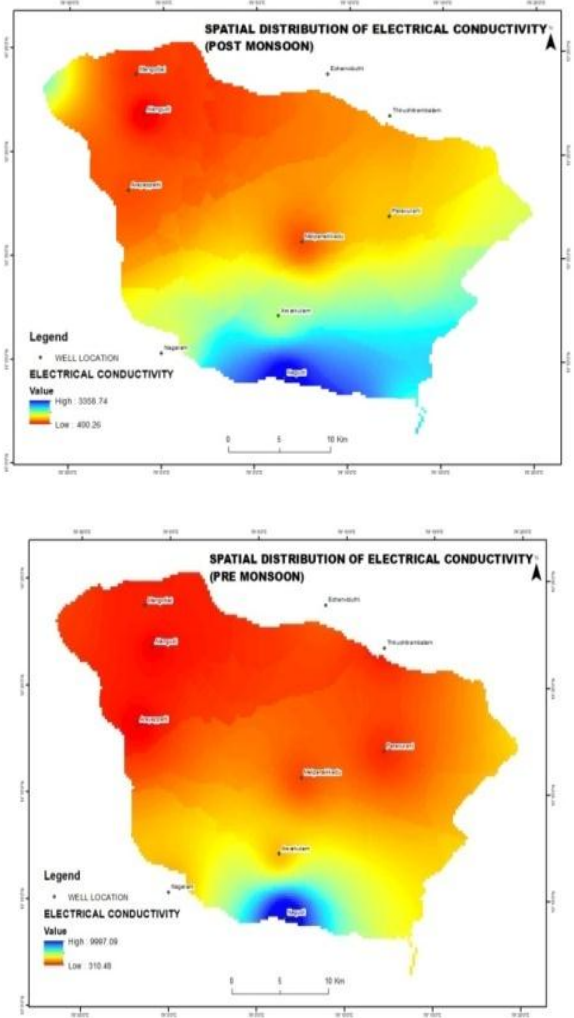

Fig.13: Thematic map showing concentration of Electrical Conductivity

\section{Result and Discussion}

Groundwater quality exhibitsspatio-temporal variation in their values. Water quality index is a method of rating groundwater for human consumption. The results provide a compositeinfluence of individual parameter in conjunction with the other parameters (Mitra and ASABE Member, 1998). Based on BIS standards(10500), index was computed. As suggested by earlier workers (Horton, 1965; Pradhan et al., 2001; Asadi et al., 2007; Vasanthavigar et al., 2010; Saeedi et al., 2010 and Yidana and Yidana, 2010) the quality index was computed.Firstly, individual weights (wi) were assigned for the above 13 parameters in conjunction with their relative importance in overall quality of water.Based on their importance, the parameters namely nitrate, TDS, chloride, fluoride and sulphatewere assigned with a maximum weight of 5 (Srinivasamoorthy et al., 2008). Since Potassium plays an insignificant role, a weight of 2 is given. While calcium, magnesium, sodium, and potassium were assigned with weight between 1 and 5 on the basis of their relative importance.

Then their relative weights (Wi) were computed using as:

$$
\mathrm{Wi}=\mathrm{wi} / \sum \sum_{i=1}{ }_{i}
$$

Where,

$$
\begin{aligned}
& \mathrm{Wi}=\text { Relative weight } \\
& \mathrm{Wi}=\text { Weight of each parameter } \\
& \mathrm{n}=\text { Number of parameters. }
\end{aligned}
$$

Subsequently, a quality rating scale (qi) is derived for each parameter as follows:

$\mathrm{qi}=(\mathrm{Ci} / \mathrm{Si}) * 100$

Where 
qi is the quality rating

$\mathrm{Ci}$ is the concentration in milligrams per liter.

Finally, water quality index is determined as:

$\mathrm{SIi}=\mathrm{Wi} * \mathrm{qi}$

$\mathrm{WQI}=\sum \mathrm{SIi}$

Where

SIi is the sub-index of $i^{\text {th }}$ parameter

qi is the rating based on concentration of $i^{\text {th }}$ parameter.

For easy understanding, the derivedwater quality index values were classified into four categories as excellent, high, moderate and poor qualities and accordingly GIS maps were generated for both the seasons separately(Figure.14).
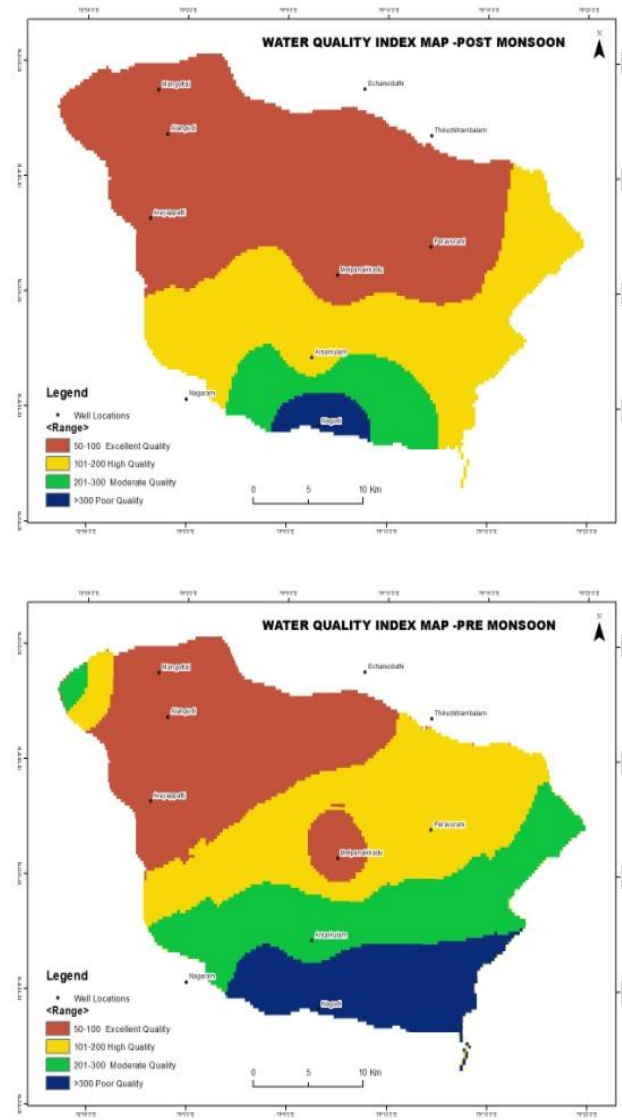

Fig. 14: Water Quality Index Map

From the above, areal extent of the all four categories during both the periods was computed. During postmonsoon period, $18 \%$ falls under "excellent", 46\% under "high", 25\% shows "moderate", and $11 \%$ of the area shows "poor" qualities. During pre-monsoon period, 34\% shows "excellent", 43\% shows "high", and remaining $23 \%$ shows "poor" qualities. Thus more than fifty percentage of the aerial extent falls under 'poor' quality category during pre-monsoon when matched with its counterpart. The spatial correlation of the groundwaterquality index map with other contaminating parameters shows that host rock namely the granitic gneiss and its associated leaching of ions as reason for the existence of 'very poor' quality in the southern part. However, the direct discharge of industrial effluents, domestic waste and sewage, and the impact of agricultural activities are inferred as the major causes of groundwater quality deterioration.

\section{Conclusion}

The study proposes a method for evaluating groundwater quality of an area with emphasis on drinking water standards. GIS has proven effective in analyzing the spatial distribution pattern of various groundwater quality parameters. The water quality index not only enables to spatially asses overall quality of groundwater but also to identify the deteriorating parameters. From the visualization of saptio-temporal pattern changes, the role of natural and anthropogenic impacts on groundwater quality is envisaged. Administrators and decision makers can utilize the water quality index method for assessing and monitoring the groundwater quality of an area.

\section{References}

[1] Ahn Hong-IL and Chon Hyo-Taek,Assessment Of Groundwater Contamination Using Geographic Information Systems Environmental Geochemistry and Health, 1999, Volume 21, Number 3, Page 273.

[2] Asadi.S.S, Vuppala, P. and AnjiReddy.M, Remote sensing and GIS techniques for evaluation of groundwater quality in Municipal Corporation of Hyderabad (Zone-V). India Int $\mathrm{J}$ Environ Res Publ Health 4(1), Pp. 45-52.(2007).

[3] BIS. (1991). Indian Standard drinking water-specification (1st rev.pp. 1-8).

[4] Horton R.K, An index number system for rating water quality. J Water Pollut Control Fed 37, pp. 300-305.(1965).

[5] Kumar, D., and Ahmed, S, Seasonal behaviour of spatial variability of groundwater level in a granitic aquifer in monsoon climate. Current Science, 84(2), pp.188-196.(2003).

[6] Milovanovic, M, Water quality assessment and determination of pollution sources along the Axios/ Vardar River, Southeastern Europe. Desalination, 213, pp. 159-173.(2007)

[7] Mitra, B. K., and ASABE Member, Spatial and temporal variation of ground water quality in sand dune area of aomori prefecture in Japan.(1998)

[8] Pradhan S.K, Patnaik, D, and Rout S.P, Water quality index for the ground water in and around a phosphatic fertilizer plant. Indian J Environ Protect 21, pp. 355-358.(2001).

[9] RangzanK,CharchiA,AsshiriniE, and Dinger J, Remote sensing and GIS approach for water-well site selection, southwest Iran. Environmental and Engineering Geoscience. Vol. 14 p. 315-326. (2008)

[10] Reddy.P.R, Vinod Kumar. K. and Seshadri. K, Use of IRS-1C data in ground water studies. Current Science Special session, IRS 1C 70(7), pp. 600-605.(1996).

[11] Saeedi. M, Abessi.O, Sharifi.F. and Meraji H, Development of groundwater quality index. Environ Monit Assess 163, pp. 327-335.(2010).

[12] Simeonov.V, Stratis.J.A, Samara.C, Zachariadis.G, Voutsa.D, and Anthemidis.A, Assessment of the surface water quality in Northern Greece. Water Research, 37, pp. 4119-4124.(2003).

[13] Srinivasamoorthy. K, Chidambaram.M, Prasanna.M.V, Vasanthavigar.M, John Peter.A. and Anandhan.P, Identification of major sources controlling Groundwater Chemistry from a hard rock terrain - A case study from Metturtaluk, Salem district, Tamilnadu, India. Journal of Earth System Sciences, 117(1), pp. 49-58.(2008).

[14] Suk.H, andLee.K, Characterization of a ground water hydrochemical system through multivariate analysis: Clustering into ground water zones. Ground Water, 37, pp. 358-366.(1999).

[15] Vasanthavigar.M,Srinivasamoorthy.K, Vijayaragavan. K, Ganthi.R.R, Chidambaram.S, Anandhan. P, Manivannan.RandVasudevan.S, Application of water quality index for groundwater quality assessment: Thirumanimuttar Sub-basin, Tamilnadu. India. Int. J. Environ Monit Assess 171(1-4), pp. 595-609.(2010).

[16] Yammani, Srinivasarao, Groundwater quality suitable zones identification: Application of GIS, Chittoor area, Andhra Pradesh, India. Environmental Geology. 53. 201-210. 10.1007/s00254-0060634-1.(2007).

[17] Yidana.S.M, Yidana.A,Assessing water quality using water quality index and multivariate analysis. Environmental Earth Science 59, pp. 1461-1473.(2010). 
Table 1: Statistics of Groundwater Chemical Parameters for Pre \& Post Monsoon

\begin{tabular}{|c|c|c|c|c|c|c|c|c|}
\hline \multirow[b]{2}{*}{ Parameters } & \multicolumn{4}{|c|}{ Pre monsoon values } & \multicolumn{4}{|c|}{ Post monsoon values } \\
\hline & Min & Max & Avg & Std & Min & Max & Avg & Std \\
\hline TDS & 0 & 6397 & 1047 & 1670 & 185 & 4301 & 1031 & 993 \\
\hline NO2_NO3 & 0.07 & 42.28 & 5 & 8 & 1 & 21 & 6 & 6 \\
\hline $\mathrm{Ca}$ & 0 & 160 & 34 & 40 & 6 & 160 & 47 & 35 \\
\hline $\mathrm{Mg}$ & 0 & 384 & 53 & 92 & 16 & 258 & 77 & 72 \\
\hline $\mathrm{Na}$ & 0 & 1863 & 270 & 445 & 17 & 1041 & 216 & 263 \\
\hline $\mathrm{K}$ & 0 & 43 & 10 & 12 & 0 & 70 & 13 & 15 \\
\hline $\mathrm{Cl}$ & 21 & 4077 & 620 & 1010 & 50 & 2099 & 390 & 468 \\
\hline SO4 & 0 & 444 & 74 & 125 & 5 & 538 & 105 & 144 \\
\hline $\mathrm{CO} 3$ & 0 & 132 & 15 & 30 & 0 & 54 & 7 & 13 \\
\hline $\mathrm{HCO} 3$ & 0 & 658.8 & 159 & 186 & 83 & 665 & 280 & 175 \\
\hline $\mathrm{F}$ & 0 & 1.5 & 0.4 & 0 & 0 & 1 & 0.5 & 0 \\
\hline $\mathrm{pH}$ & 7 & 9 & 8 & 0 & 7 & 9 & 8 & 0 \\
\hline EC & 310 & 10620 & 2248 & 2778 & 340 & 7420 & 1841 & 1734 \\
\hline
\end{tabular}

Where: TDS - Total Dissolved Solids, NO3 - Nitrate, Ca - Calcium, Mg Magnesium, Na - Sodium, K - Potassium, Cl - Chloride, SO4 - Sulphate, CO3 HCO3 - Bicarbonate, Fe - Iron, pH, EC- Electrical Conductivity,Hardness Min - Minimum, Max - Maximum, Avg - Average \& Std - Standard Deviation 